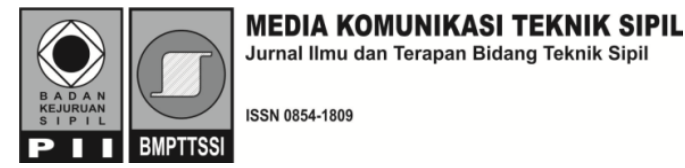

\title{
Pengaruh Perubahan Iklim terhadap Hidrograf Banjir di Kanal Banjir Timur Kota Semarang
}

\author{
Suripin \\ Departemen Teknik Sipil Fakultas Teknik-Universitas Diponegoro \\ Jl. Prof. Soedarto, SH, Tembalang, Semarang 50275 \\ E-mail: suripin.ar@gmail.com \\ Dwi Kurniani \\ Departemen Teknik Sipil Fakultas Teknik-Universitas Diponegoro \\ J1. Prof. Soedarto, SH, Tembalang, Semarang 50275 \\ E-mail:dwik_ani@yahoo.com
}

\begin{abstract}
East Flood Way is one of the rivers in Semarang City that often cause flooding. Flood water level in the East Flood Way is affected by the discharge of storm water runoff and tide (rob). Facts on the ground indicate that the flood water level in the canal tends to increase from year to year. One possible reason is the increased flood discharge associated with climate change, besides the impacts of land use changes. This study aims to analyze the impacts of climate change on rainfall characteristics and their effects on flood hydrograph in the East Flood Way. The study begins with the collection and analysis of historical rainfall data to get a change of rainfall characteristics over time. The flood hydrograph was then analysed by HEC $H M S$. The results showed that in the period of last 30 years annual rainfall and maximum daily rainfall tended to increase of $22.64 \mathrm{~mm} /$ year and $2.56 \mathrm{~mm} /$ year consecutively, while the number of rainy days tend to decrease of 4 days / year. As a result of changes in the characteristics of the rainfall, the flood discharge of East Flood Way is expected to increase in the range between the $15.10 \mathrm{~m}^{3} / \mathrm{s}(31.5 \%)$ for 2 -year return period up to $32.28 \mathrm{~m}^{3} / \mathrm{s}(25.5 \%)$ for 200-year return period.
\end{abstract}

Keywords: Flood hydrograph, Rainfall characteristics, Climate change.

\begin{abstract}
Abstrak
Kanal Banjir Timur adalah salah satu sungai di Kota Semarang yang sering menyebabkan banjir. Tinggi muka air banjir di alur Kanal Banjir Timur (KBT) dipengaruhi oleh debit dari limpasan air hujan dan pasang surut air laut (rob). Fakta di lapangan menunjukkan bahwa muka air banjir di KBT cenderung makin meningkat dari tahun ke tahun. Salah satu kemungkinan penyebabnya adalah meningkatnya debit banjir terkait dengan perubahan iklim, di samping akibat perubahan penutupan lahan. Penelitian ini bertujuan untuk menganalisis dampak perubahan iklim terhadap karakteristik hujan serta pengaruhnya terhadap hidrograf banjir di Kanal Banjir Timur. Penelitian diawali dengan pengumpulan dan analisis data hujan historis untuk mendapatkan perubahan karakteristik hujan terhadap waktu, selanjunya dilakukan analisis hidrograf banjir dengan HEC HMS. Hasil kajian menunjukkan bahwa dalam kurun waktu 30 tahun terakhir tinggi hujan tahunan dan harian maksimum cenderung meningkat masing-masing 22,64 mm/tahun, dan $2,56 \mathrm{~mm} /$ tahun, sedangkan jumlah hari hujan cenderung berkurang rata-rata 4 hari/tahun. Akibat dari perubahan karakteristik hujan tersebut, debit banjir rencana DAS Kanal Banjir Timur diprediksi akan mengalami kenaikan berkisar antara dengan $15,10 \mathrm{~m}^{3} / \mathrm{s}(31,5 \%)$ untuk kala ulang 2-tahunan sampai 32,28 $\mathrm{m}^{3} / \mathrm{s}(25,5 \%)$ untuk debit kala ulang 200-tahunan.
\end{abstract}

Kata-kata Kunci: Hidrograf banjir, Karakteristik hujan, Perubahan iklim. 


\section{Pendahuluan}

Kejadian banjir di Kota Semarang secara faktual menujukkan kecenderunagn makin meningkat dari waktu ke waktu, baik dilihat dari frekuensi kejadiannya maupun luas, kedalaman, dan lamanya genangan. Salah satu sungai yang sering meimbulkan banjir adalah Kanal Banjir Timur $(\mathrm{KBT})$, yang termasuk ke dalam Sistem Drainase Semarang Timur. Banyak faktor yang menyebabkan peningkatan banjir di Kota Semarang, yang dominan adalah alih fungsi lahan, dampak perubahan iklim dan penurunana lahan. Pengaruh perubahan tata guna lahan terhadap limpasan permukaan sudah banyak diteliti dan dibahas diberbagai seminar, demikian juga penurunan lahan. Sementara pengaruh perubahan iklim terhadap perubahan hidrologi belum banyak dibahas dan diperhitungkan dalam pengelolaan sistem drainase dan pengendalian banjir. Beberapa penelitian menyebutkan bahwa perubahan iklim telah membawa perubahan karakteristik hujan. Secara umum durasi musim hujan makin pendek, sebaliknya durasi musim kemarau makin panjang. Jumlah hari hujan cenderung makin menurun, sementara hujan harian maksimum dan intensitas hujan cenderung makin meningkat (Suripin \& Hilmi, 2015).

Pengembangan sistem drainase dan/atau pengendalian banjir konvensional pada umumnya belum memasukkan faktor perubahan iklim terhadap hidrograf banjir. Hujan rencana masih didasarkan pada analisis probabilitas data historis. Oleh karena itu, berdasarkan kondisi dan kenyataan tersebut, maka perlu adanya kajian pengaruh perubahan iklim terhadap perubahan hidrograf banjir di Kota Semarang. Penelitian ini bertujuan untuk menemukan konstibusi perubahan iklim terhadap perubahan hidrograf banjir di Kanal Banjir Timur Kota Semarang. Dengan temuan penelitian ini, diharapkan pengembangan sistem drainase dan/atau pengendalian banjir konvensional yang selama ini dianut, khususnya dalam prediksi banjir, dapat disempurnakan.

\section{Tinjauan pustaka}

Perubahan iklim akibat pemanasan global atau global warming sudah bukan isue lagi, namun sudah menjadi kenyataan, yang dampaknya sudah dapat dirasakan bersama. Pemanasan global adalah proses peningkatan suhu rata-rata atmosfer, laut, dan daratan Bumi. Berdasarkan Laporan IPCC (2007) disebutkan bahwa perubahan iklim ditandai dengan adanya perubahan beberapa paramer iklim atau kejadian, antara lain:

a. perubahan suhu permukaan bumi

b. perubahan curah hujan c. perubahan pada kejadian cuaca ekstrim

d. perubahan tutupan es/salju

e. perubahan tinggi muka laut

Analisis perubahan iklim (climate change) dilakukan karena melihat besarnya dampak yang dihasilkan dari perubahan iklim ini terhadap ketersediaan sumber daya alam (SDA). WWF (2012) dalam studinya di wilayah Indonesia menunjukkan bahwa dalam periode 100 tahun ini telah terjadi kenaikan suhu rata-rata tahunan hingga $0,72-3,92^{\circ} \mathrm{C}$ yang disertai dengan penurunan presipitasi hujan hingga $2-3 \%$. Studi ini juga menunjukkan bahwa di wilayah Indonesia bagian selatan telah terjadi pergeseran musim hujan hingga satu bulan lebih lambat dengan terjadinya kenaikan intensitas curah hujan hingga $10 \%$ di musim hujan dan penurunan $75 \%$ intensitas curah hujan di musim kemarau. Sebagian besar peningkatan suhu rata-rata global sejak pertengahan abad ke-20 kemungkinan besar disebabkan oleh meningkatnya konsentrasi gas-gas rumah kaca (GRK) akibat aktivitas manusia melalui efek rumah kaca (IPPC, 2008).

Berubahnya komposisi gas rumah kaca (GRK) di atmosfer, yaitu meningkatnya konsentrasi GRK secara global akibat kegiatan manusia menyebabkan sinar matahari yang tidak terserap permukaan bumi akan dipantulkan kembali dari permukaan bumi ke angkasa. Setelah dipantulkan kembali berubah menjadi gelombang panjang yang berupa energi panas. Namun sebagian dari energi panas tersebut tidak dapat menembus kembali atau lolos keluar ke angkasa, karena lapisan gas-gas atmosfer sudah terganggu komposisinya. Akibatnya energi panas yang seharusnya lepas keangkasa (stratosfer) menjadi terpantul kembali ke permukaan bumi (troposfer), sehingga energi di permukaan bumi melebihi kondisi normal. Komposisi lapisan gas rumah kaca di atmosfer menjadi terganggu, akibatnya memicu naiknya suhu rata-rata dipermukaan bumi maka terjadilah pemanasan global. Karena suhu adalah salah satu parameter dari iklim dengan begitu berpengaruh pada iklim bumi, terjadilah perubahan iklim secara global.

Salah satu indikasi terjadinya perubahan iklim adalah perubahan pola hujan, akibat adanya anomali iklim seperti siklon tropis dan kejadian El Nino dan La Nina. Hujan merupakan unsur fisik lingkungan yang paling bervariasi, terutama di daerah tropis. Boer (2003) mengatakan bahwa hujan merupakan unsur iklim yang paling penting di Indonesia karena keragamannya sangat tinggi baik menurut waktu maupun tempat, oleh karena itu kajian tentang iklim lebih banyak diarahkan pada faktor hujan. 
Hujan dipandang sebagai salah satu variabel peramalan cuaca dan iklim yang sangat penting karena mempengaruhi aktivitas kehidupan manusia di berbagai sektor seperti pertanian, perhubungan, perdagangan, kesehatan, lingkungan hidup dan sebagainya (Turyanti, 2006). Namun demikian, hujan merupakan salah satu variabel atmosfer yang paling sulit diprediksi, dan pada saat ini masih merupakan tantangan yang besar bagi para peneliti meteorologi. Banyak model yang digunakan di dunia pada saat ini, belum satupun yang dapat memberi prediksi hujan yang cukup baik, terutama untuk wilayah katulistiwa. Wilayah ini memang memiliki tingkat non-liearitas yang tinggi, sehingga kondisi atmosfer di wilayah ini lebih sulit diprediksi dibandingkan dengan wilayah di lintang tinggi. Karena faktor penyebab hujan itu sangat banyak. Secara umum keragaman hujan di Indonesia sangat dipengaruhi oleh keberadaannya di garis katulistiwa, aktifitas moonson, bentangan samudera Pasifik dan Hindia serta bentuk topografi yang sangat beragam. Gangguan siklon tropis (ElNino, La-Nina, Madden Julian Oscillation (MJO) dan angin badai) diperkirakan juga ikut berpengaruh terhadap keragaman curah hujan.

Selama ini, secara empiris para ilmuwan telah mengetahui bahwa pemanasan global akan meningkatkan curah hujan. Curah hujan ekstrem di wilayah tropis lebih sensitif terhadap pengaruh perubahan iklim dibandingkan wilayah-wilayah lain di dunia. Namun mekanisme peningkatan curah hujan ini belum bisa dipahami dengan baik (O'Gorman, 2015). Penelitian terbaru dari Massachusetts Institute of Technology (MIT) menemukan, jika suhu bumi naik 1 derajat Celsius, hujan ekstrem di wilayah tropis akan bertambah lebat hingga 10\%. Dampak meningkatnya intensitas hujan ekstrem ini adalah potensi banjir di wilayah-wilayah yang padat penduduk di daerah tropis.

\section{Perubahan karakteristik hujan}

Perubahan iklim adalah perubahan rata-rata salah satu atau lebih elemen cuaca pada suatu daerah tertentu (LAPAN, 2002). Ada beberapa elemen cuaca, diantaranya suhu udara, kecepatan dan arah angin, evaporasi, dan curah hujan. Perubahan elemen cuaca ini terjadi dalam kurun waktu yang panjang atau bahkan sangat panjang. Sementara istilah perubahan iklim skala global adalah perubahan iklim dengan acuan wilayah bumi secara keseluruhan pada variasi rata-rata kondisi iklim suatu tempat atau pada variabilitasnya yang nyata secara statistik untuk jangka waktu yang panjang. Perubahan iklim terjadi karena proses alam internal maupun ada kekuatan eksternal, atau akibat kegiatan manusia yang terus menerus mengubah komposisi atmosfer dan tata guna lahan (Murdiyarso, 2003). Pemanasan iklim lebih lanjut juga dapat menyebabkan badai tropis lebih intens (Emanuel, 2005). Karakteristik hujan berubah, hujan harian dan intensitas hujan cenderung meningkat, diikuti dengan makin meningkatnya debit banjir, mengakibatkan lebih banyak orang beresiko dan meningkatkan kerusakan, kehilangan, dan kerugian.

Beberapa dekade terakhir ini, makin sering terjadi peristiwa iklim ekstrem dengan dampak yang makin parah. Dalam periode tahun 1844 - 1960 kemarau panjang terjadi rata-rata setiap empat tahun, tetapi antara tahun 1961 - 2006 meningkat menjadi setiap tiga tahun. Banjir juga makin sering melanda, antara tahun 2001-2004, terjadi sekitar 530 kali banjir, yang melanda hampir di seluruh provinsi, dengan tingkat kerusakan juga meningkat. Kejadian El Niño 1997-1998 adalah yang paling parah selama 50 tahun; tahun 1998 memang merupakan tahun terpanas dalam abad dua puluh ini (PEACE, 2007). Di masa akan datang, sebagian wilayah Indonesia, terutama wilayah yang terletak di sebelah selatan katulistiwa, dapat mengalami musim kemarau yang lebih panjang dan musim hujan yang lebih pendek tetapi dengan curah yang lebih tinggi.

\section{Hidrograf banjir}

Hidrograf dapat didefinisikan sebagai hubungan antara salah satu unsur aliran terhadap waktu. Berdasarkan definisi tersebut dikenal ada dua macam hidrograf, yaitu hidrograf muka-air, dan hidrograf debit. Hidrograf muka-air tidak lain adalah data atau grafik hasil rekaman AWLR (Automatic Water Level Recorder). Sedangkan hidrograf debit, yang dalam pengertian sehari-hari disebut hidrograf banjir, diperoleh dari hidrograf muka-air dan lengkung debit. Dalam penelitian ini, yang dimaksud hidrograf adalah hidrograf banjir.

Hidrograf tersusun dari dua komponen, yaitu aliran permukaan, yang berasal dari aliran langsung air hujan, dan aliran dasar (base flow). Aliran dasar berasal dari air tanah, yang pada umumnya tidak memberikan respon yang cepat terhadap hujan. Hujan juga dapat dianggap terbagi dalam dua komponen, yaitu hujan efektif, dan kehilangan (losses). Hujan efektif adalah bagian hujan yang menyebabkan terjadinya aliran permukaan. Kehilangan hujan merupakan bagian hujan yang menguap, masuk kedalam tanah kelembaban tanah, dan simpanan air tanah.

Hidrograf banjir pada sutau daerah aliran sungai (DAS) tergantung dari berbagai faktor secara bersamaan. Faktor-faktor yang berhubungan 
dengan limpasan, yang dibagi dalam dua kelompok, yakni elemen-elemen meteorologi yang diwakili oleh curah hujan dan elemen-elemen yang menyatakan sifat-sifat fisik DAS.

Pada saat ini, telah banyak berkembang modelmodel hujan - aliran. Model tersebut digunakan dalam perencanaan pengelolaan sumber daya air. Model hujan-aliran yang telah banyak diaplikasikan di Indonesia dan memberikan hasil cukup memuaskan adalah HEC-HMS.

\section{Model Hidrograf Banjir}

HEC-HMS (Hydrologic Engineering Center's Hydrologic Modeling System) adalah perangkat lunak yang dikembangkan oleh U.S Army Corps of Engineering. HEC-HMS digunakan untuk analisis hidrologi dengan mensimulasikan proses curah hujan dan limpasan langsung (run off) dari sebuah wilayah sungai. Software ini didesain untuk bisa diaplikasikan dalam area geografik yang sangat luas untuk menyelesaikan masalah, meliputi suplai air daerah pengaliran sungai, hidrologi banjir, dan limpasan air di daerah kota kecil ataupun kawasan tangkapan air alami. Hidrograf satuan yang dihasilkan dapat digunakan langsung ataupun digabungkan dengan software lain yang digunakan dalam ketersediaan air, drainase perkotaan, ramalan dampak urbanisasi, desain pelimpah, pengurangan kerusakan banjir, regulasi penanganan banjir, dan sistem operasi hidrologi (USACE, 2010).

Model HEC - HMS dapat memberikan simulasi hidrologi dari puncak aliran harian untuk perhitungan debit banjir rencana dari suatu DAS. Model HEC-HMS mengemas berbagai macam metode yang digunakan dalam analisis hidrologi. Dalam pengoperasiannya menggunakan basis sistem windows, sehingga model ini menjadi mudah dipelajari dan mudah untuk digunakan, tetapi tetap dilakukan dengan pendalaman dan pemahaman dengan model yang digunakan. Di dalam model HEC-HMS mengangkat teori klasik hidrograf satuan untuk digunakan dalam permodelannya, antara lain hidrograf satuan sintetik Synder, Clark, SCS, ataupun kita dapat mengembangkan hidrograf satuan lain dengan menggunakan fasilitas user define hydrograph (USACE, 2010). Sedangkan untuk menyelesaikan analisis hidrologi ini, digunakan hidrograf satuan sintetik dari SCS (soil conservation service) dengan menganalisis beberapa parameternya.

\section{Metode Penelitian dan Bahan}

Penelitian akan dilakukan di Kanal Banjir Timur di Kota Semarang, yang merupakan sub-sistem drainase dari Sistem Drainase Semarang Timur. Lokasi ini dipilih karena beberapa hal antara lain:

1. Kanal Banjir Timur merupakan salah satu sungai yang paling sering menimbulkan banjir di Kota Semarang

2. Wilayah yang tergenang banjir dari Kanal Banjir Timur berupa kompleks perumahan, kawasan industri, dan kawasan komersial lainnya

3. Kanal Banjir Timur dapat mewakili sungaisungai lain di Kota Semarang, sehingga hasilnya dapat digunakan untuk menganalisis sungai-sungai lain di Kota Semarang.

Data hujan yang digunakan berasal dari 3 (tiga) pos hujan: Stasiun Pos Hujan (SPH): SPH Pucanggading, SPH Maritim, dan SPH Simongan, dengan panjang data 30 tahun. SPH Pucanggading dan SPH Simongan berupa pos hujan manual, sedangkan SPH Maritim berupa pos hujan otomatis. Pelaksanaan penelitian secara keseluruhan mengikuti bagan alir pada Gambar 1.

\section{Prediksi perubahan karakteristik hujan}

Elemen cuaca yang berpengaruh pada perubahan hidrograf banjir adalah suhu udara dan karakteristik hujan. Suhu udara berpengaruh pada hampir seluruh komponen siklus hidrologi, mulai dari penguapan, angin yang menggerakkan uap air, hujan, dan juga kenaikan muka air laut. Prediksi pengaruh perubahan iklim terhadap elemen cuaca dilakukan dengan analisis regresi terhadap data historis elemen cuaca untuk mendaptkan korelasi antara elemen cuaca dan waktu. Analisis regresi dilakukan terhadap, tinggi hujan tahunan, jumlah hari hujan, tinggi hujan harian maksimum, dan intensitas hujan.

\section{Prediksi hidrograf banjir}

Ada banyak faktor yang berpengaruh pada debit banjir, yang secara umum dapat dikelompokkan menjadi faktor statis dan dinamis. Factor statis meliputi geologi dan jenis tanah, dan topografi, sedangkan faktor dinamis meliputi penutupan lahan, dan karakteristik hujan.

Analisis debit banjir dilakukan dengan menggunakan perangkat lunak "HEC-HMS". Luaran dari perangkat lunak ini antara lain hidrograf banjir dan debit puncak. Perubahan hidrograf banjir diperoleh dengan membandingkan hidrograf banjir akibat hujan pada saat sekarang dan hidrograf banjir yang ditimbulkan oleh prediksi hujan di masa yang akan datang. 


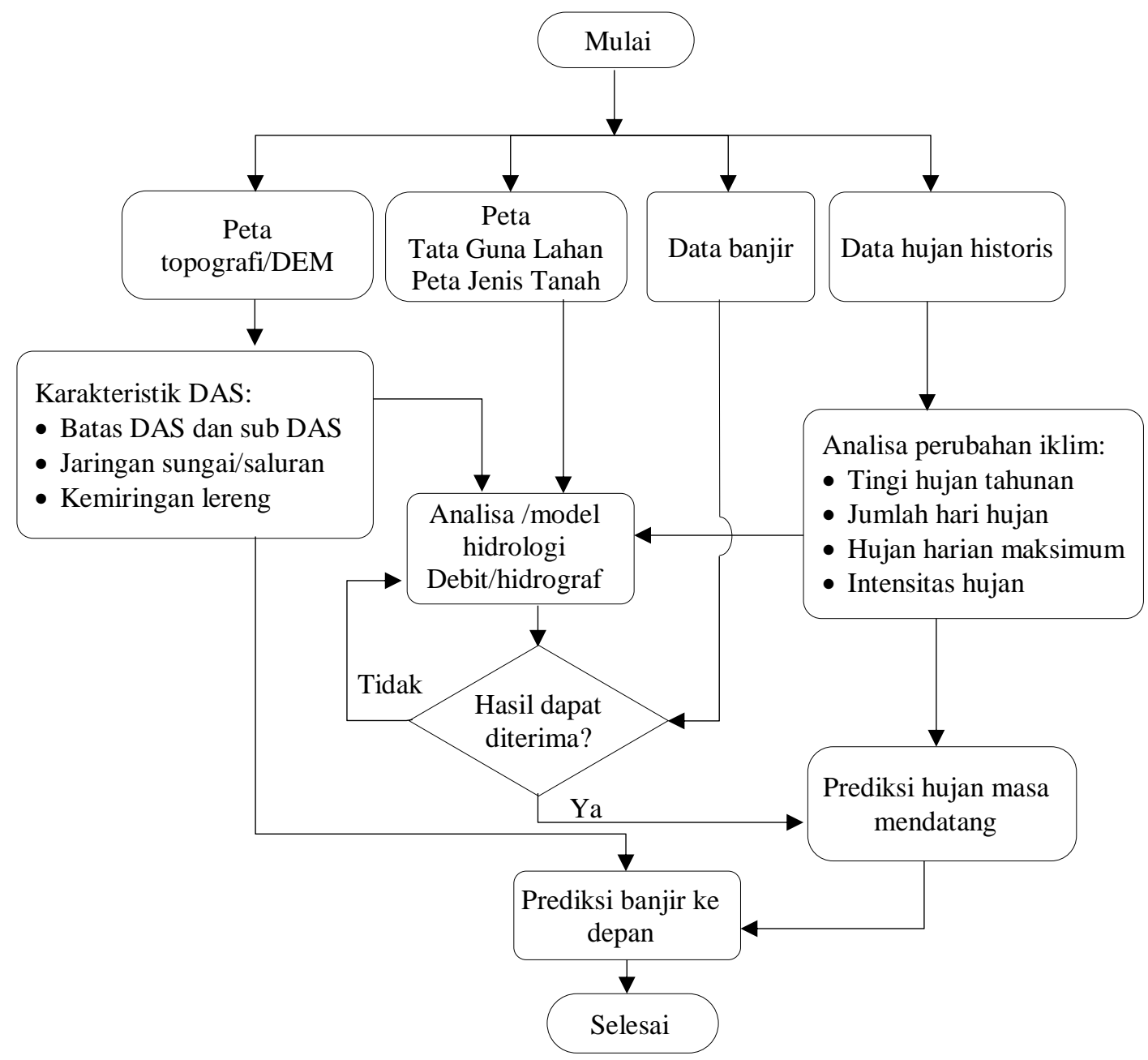

Gambar 1. Alur pelaksanaan penelitian pengaruh perubahan iklim terhadap hidrograf Banjir di Kanal Banjir Timur Kota Semarang

\section{Analisa Data dan Pembahasan}

\section{Karakteristik Kanal Banjir Timur (KBT)}

Kanal Banjir Timur dibangun pada 1896 untuk mengalirkan air dari daerah perbukitan di selatan Kota Semarang ke Laut Jawa. Luas daerah tangkapan adalah bantaran sungai yang menyempit dan pendangkalan, penyempitan bantaran sungai ini akibat dari bangunan - bangunan liar. Kanal Banjir Timur saat ini merupakan bagian dari Sistem Dolok-Penggaron yang meliputi beberapa sungai. Sumber air yang masuk ke sistem meliputi Kali Penggaron, Kali Dolok, Kali Candi, Kali Bajak dan Kali Kedung Mundu. Muaranya ada empat yaitu Banjir Kanal Timur, Kali Babon, Kali Tawang-Dombo-Sayung dan Kali DolokPenggaron. Penelitian ini hanya memperhitungkan DAS Kanal Banjir Timur (Gambar 2). Banjir yang dikendalikan oleh Bendung Pucanggading tidak termasuk dalam penelitian ini. Hal ini mengingat bahwa debit yang dilepas dari Bendung Pucanggading ke Kanal Banjir Timur dikendalikan dan dibatasi maksimum $100 \mathrm{~m}^{3} / \mathrm{s}$.

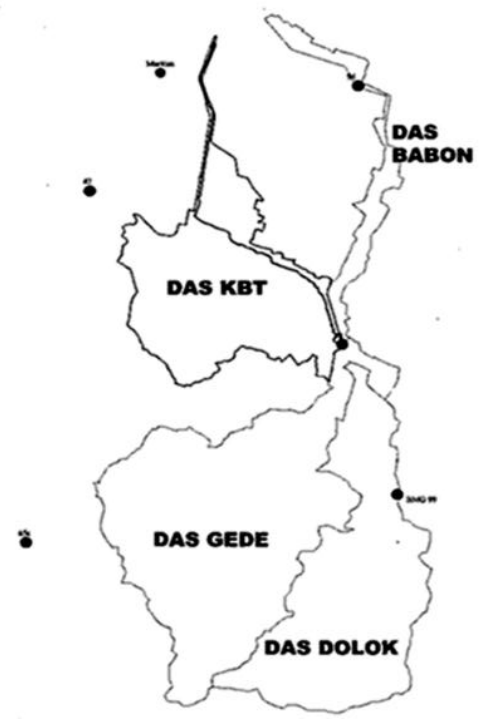

Gambar 2. DAS Kanal Banjir Timur 


\section{Tata guna lahan}

Data tata guna lahan diperlukan sebagai masukan untuk analisis hidrograf banjir dengan model HECHMS, yaitu untuk menganalisis curve number. Data tata guna lahan yang digunakan dalam penelitian ini berdasar peta tata guna lahan seri tahun 2014. Peta ini diperoleh dari beberapa sumber seperti BBWS Pemali Juana dan Pemerintah Kota Semarang. Komposisi penggunaan lahan pada tahun 2014 terdiri dari belukar 19,39\%; empang 1,73\%; perkotaan $8,10 \%$; permukiman $23,33 \%$; kebun $21,36 \%$; sawah $5,90 \%$ dan tegalan $20,18 \%$.

\section{Jenis tanah}

Informasi jenis tanah digunakan dalam analisis nilai curve number yang merupakan input dalam model HEC-HMS. Peta jenis tanah yang digunakan dalam analisis merupakan peta keluaran dari Pusat Penelitian Tanah, Bogor. Jenis tanah di DAS Kanal Banjir Timur didominasi oleh Asosiasi Alluvial Kelabu 64,21\%; Mediteran Coklat Tua 27,02\%; Regosol 7,82\%; dan sebagian kecil Latosol Coklat Kemerahan 0,73\%; dan Alluvial 0,22\%. Jenis tanah Asosiasi Alluvial Kelabu dan Alluvial terdapat pada bagian hulu, sedangkan bagian hilir didominasi Mediteran Coklat Tuan dan sedikit Grumusol. Jenis tanah aluvial adalah tanah yang dibentuk dari lumpur sungai yang mengendap di dataran rendah yang memiliki sifat tanah yang subur dan cocok untuk lahan pertanian. Sedangkan tanah grumusol adalah tanah yang terbentuk dari material halus berlempung. Jenis tanah ini berwarna kelabu hitam dan bersifat subur. Tanah grumusol pada umumnya mempunyai tekstur liat dan mudah pecah saat musim kemarau.

\section{Data hujan}

Stasiun penakar hujan yang dipasang di Wilayah Kota Semarang cukup banyak yang tersebar di hampir merata di seluruh wilayah. Kondisi dan ketersediaan data masingmasin stasiun sangat beragan, tergantung pada instansi penanggungjawabnya. Stasiun hujan yang berada dan/atau berdekatan dengan DAS Kanal Banjir Timur ada 3 (tiga) stasiun, Stasiun Penakar Hujan (SPH) Maritim, SPH Pucanggading, dan SPH Simongan (Gambar 3).

\section{Perubahan karakteristik hujan}

Prediksi perubahan karakteristik hujan dilakukan dengan analisis regresi terhadap data hujan untuk mendapatkan korelasi antara elemen hujan dan waktu. Elemen hujan yang dikaji meliputi tinggi curah hujan tahunan, jumlah hari hujan, dan tinggi hujan harian maksimum.

Analisis perubahan karakteristik hujan dilakukan terhadap stasiun hujan yang mempunyai rekaman data cukup panjang, dalam hal ini 30 tahun. Hal ini dimaksudkan untuk mengetahui karakteristik hujan pada masing-masing kecenderungan karakteristik masing-masing elemen hujan ditampilkan pada Gambar 4. Tinggi hujan tahunan dan hujan harian maksimum cenderung mengalami peningkatan, sedangkan jumlah hari hujan cenderung menurun. Tinggi hujan tahunan meningkat rata-rata 22,64 mm/tahun, sedangkan hujan harian maksimum meningkat rata-rata $2,56 \mathrm{~mm} /$ tahun, dan jumlah hari hujan berkurang rata-rata 4 hari/tahun.

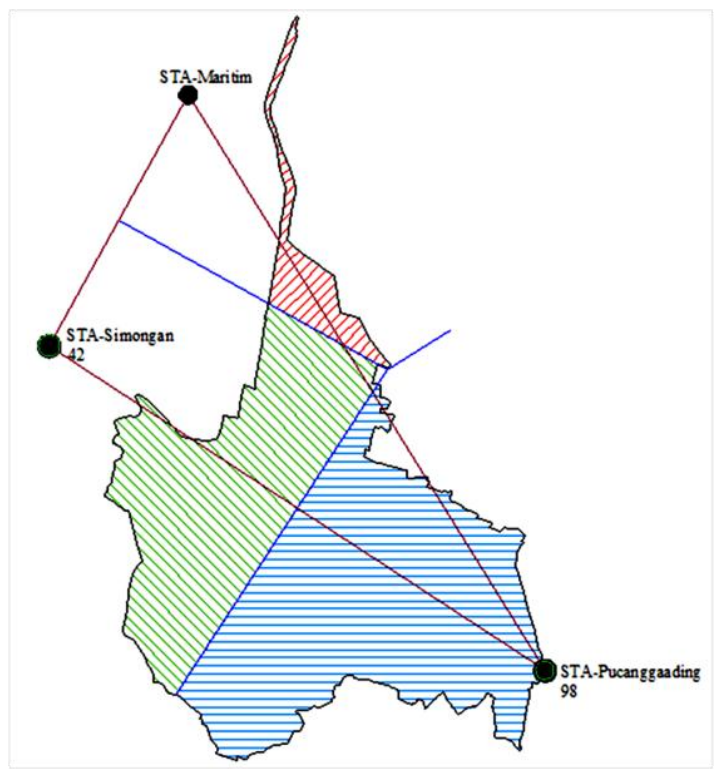

Gambar 3. Peta sebaran pos hujan di DAS KBT dan Poligon Thiessen 

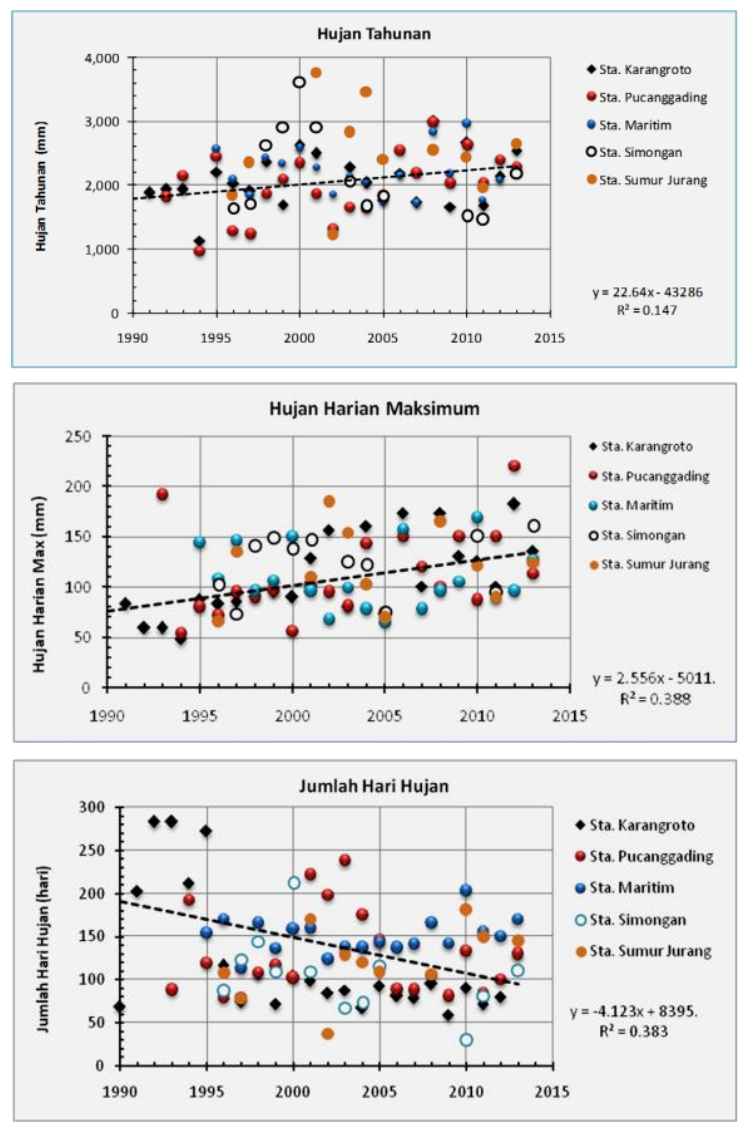

\section{Gambar 4. Kecenderungan perubahan karakteristik hujan terhadap waktu}

\section{Hujan Rencana}

Hujan DAS dihitung dengan menggunakan Metode Thiessen, sebagaimana dapat dilihat pada Gambar 3. Luas pengaruh masing-masing stasiun hujan dan Koefisien Poligon Thiessen adalah SPH Maritim $6,1 \%$, SPH Pucanggadig 38,3\%, dan SPH Simongan $56,6 \%$.

Hujan harian maksimum untuk DAS Kanal Banjir Timur dihitung dengan menyeleksi hujan harian maksium pada masing-masing stasiun. Tiap tahun diambil satu data hujan harian maksimum per SPH, sehingga diperoleh 3 hujan harian maksimum titik. Ketiga hujan harian masimum tersebut kejadiannya bisa pada tanggal yang bersamaan, bisa juga pada tanggal yang berbeda. Untuk tanggal kejadian yang berbeda, maka pada tanggal yang sama dicari tinggi hujan di 2 stasiun lainnya. Tiap tahun akan diperoleh 3 hujan DAS, dipilih yang terbesar, sebagai hujan harian maksimum kawasan.

Ada beberapa jenis distribusi yang sering digunakan dalam analisis frekuensi untuk hidrologi. Persyaratan untuk masing-masing distribusi berbeda, sehingga perlu dilakukan evaluasi terhadap data yang dianalisis untuk menentukan distribusi yang cocok. Hasil analisis menunjukkan bahwa data hujan harian maksimum mengikuti distribusi Log Person III. Dengan menggunakan nilai-nilai tersebut dihutung tinggi hujan dengan berbagai kala ulang tertentu. Hasil perhitungan hujan rencana saat ini dan prediksi yang akan datang akibat perubahan karakteristik hujan diberikan pada Tabel 1 berikut:

Tabel 1. Hujan rencana saat ini dan prediksi yang kaan datang

\begin{tabular}{crc}
\hline $\begin{array}{c}\text { Periode ulang } \\
\text { (tahun) }\end{array}$ & \multicolumn{2}{c}{ Hujan rencana $(\mathbf{m m})$} \\
\cline { 2 - 3 } & Saat ini & $\begin{array}{c}\text { Prediksi yang } \\
\text { akan datang }\end{array}$ \\
\hline 2 & 89,44 & 112,47 \\
5 & 121,13 & 151,11 \\
10 & 140,98 & 175,19 \\
25 & 165,04 & 204,28 \\
50 & 182,03 & 224,74 \\
100 & 198,52 & 244,58 \\
200 & 214,67 & 263,87 \\
\hline
\end{tabular}

\section{Hyetograf}

Hidrograf hujan dikembangkan berdasarkan data hujan jam-jaman yang tersedia di Stasiun Penakar 
Hujan Maritim. Dipilih data hujan harian dengan tinggi hujan $>50 \mathrm{~mm}$. Data hujan yang diperoleh dikelompokkan berdasarkan durasi hujan, mulai durasi 2-jam, 3-jam, 4-jam, dan 5-jam. Cari tinggi hujan tiap jam untuk masing-masing kejadian hujan. Hitung rata-rata tiap jam dan nyatakan dalam Persen. Hasil pengembangan untuk berbagai durasi hujan ditampilkan dalam bentuk grafik pada Gambar 5.

\section{Hyetograf yang menimbulkan debit puncak terbesar}

Puncak banjir terbesar untuk tinggi hujan rencana yang sama diperoleh dengan melakukan simulasi hujan-aliran dengan berbagai durasi hujan, yaitu durasi hujan 2-jam, 3-jam, 4-jam, dan 5-jam. Hasil simulasi, sebagaimana dapat dilihat pada Gambar 6. Dari Gambar 6 terlihat bahwa puncak debit banjir maksimum terjadi pada durasi hujan 2jam. Hal ini terjadi karena waktu konsentrasi diperkirakan berkisar antara $2-4$ jam. Karena sifatnya hanya memilih durasi hujan yang menimbulkan debit puncak tertinggi, maka pada dasarnya dapat digunakan sembarang tinggi hujan. Dalam penelitian ini dicoba menggunakan hujan rencana dengan kala ulang 25-tahunan.

\section{Hidrograf banjir rencaan kondisi saat ini}

Hidrograf banjir rencana saat ini dianalisis berdasarkan analiasis hujan rencana yang diperoleh dari data periode 1995-2013. Masing-masing hujan rencana dengan kala ulang tertentu yang diperoleh selanjutnya diasumsikan mempunyai durasi hujan 2-jam, dengan distribusi sebagaimana ditunjukkan dalam hyetograf pada Gambar 5. Hasil analisis secara visual ditampilkan pada Gambar 7 .

Kapasitas Kanal Banjir Timur saat ini sekitar $100 \mathrm{~m}^{3} / \mathrm{s}$ atau setara dengan debit banjir dengan kala ulang 50-tahunan.

Berdasarkan hasil simulasi tersebut, maka debit banjir dengan kala lainnya diprediksi dengan menggunakan hujan rencana dengan durasi hujan 2-jam.

\section{Prediksi hidrograf banjir rencaan kondisi mendatang}

Debit banjir mendatang diprediksi akan mengalami peningkatan sejalan dengan perubahan karakteristik hujan, di mana tinggi hujan harian maksimum cenderung makin meningkat. Hujan harian maksimum cenderung meningkat sebesar 2,556 mm/tahun. Dengan asumsi karakteristik statistik hujan maksimum harian masa yang akan datang sama dengan data historis, maka hujan harian maksimum masa yang akan datang dapat dibangkitkan. Analisis frekuensi dengan metode Log Person III dari data hujan harian maksimum hasil bangkitan ditampilkan dalam Tabel 2 . Distribusi hujan terhadap waktu diasumsikan tidak berubah.

Dengan mengasumsikan faktor yang mempengaruhi limpasan tetap, kecuali tinggi hujan rencana, maka hidrograf banjir untuk masa mendatang dapat dipredisksi. Hasil analisis secara visual ditampilkan pada Gambar 8.
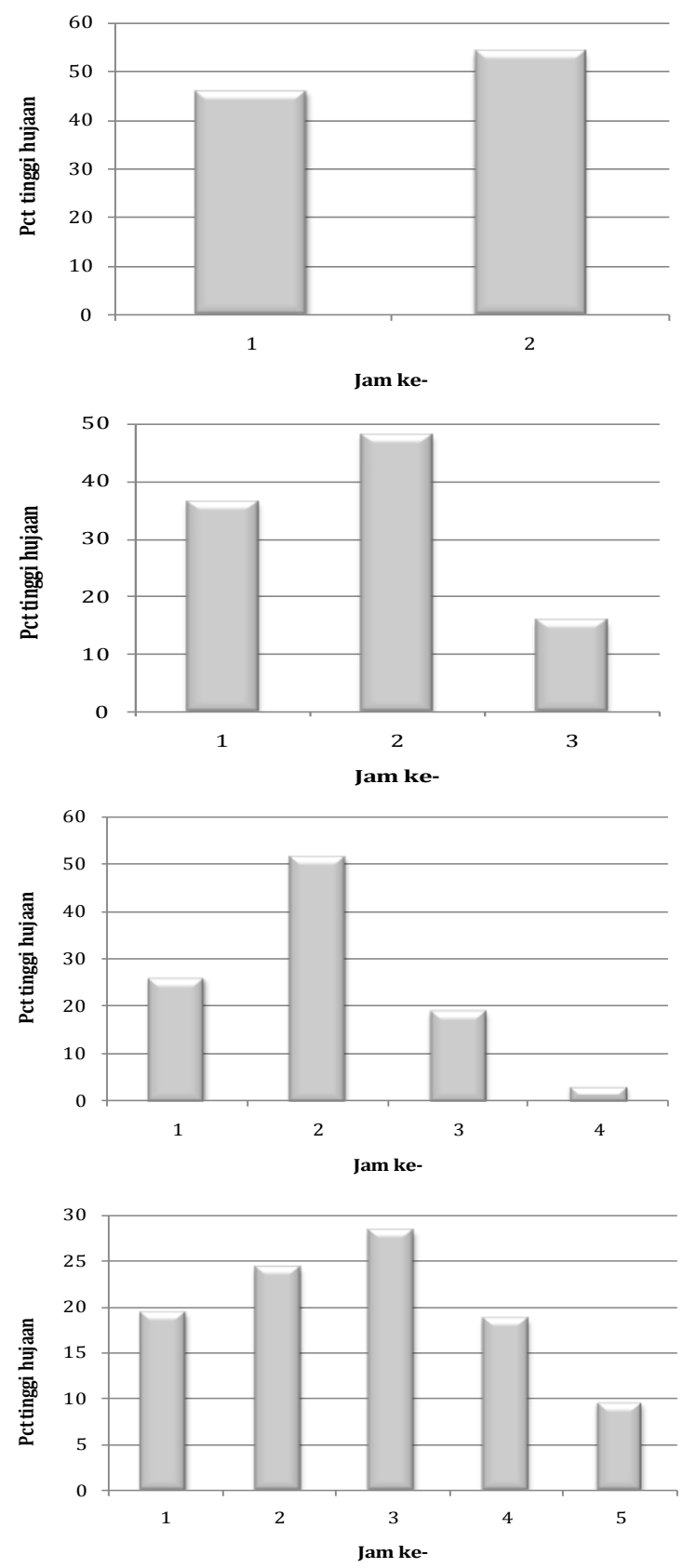

Gambar 5. Hyetograf hujan DAS Kanal Banjir Timur berbagai durasi hujan 
Pengaruh perubahan iklim terhadap hidrograf banjir di kanal banjir timur

Pengaruh perubahan iklim terhadap puncak banjir diperoleh dengan mengurangkan puncak banjir hasil prediksi untuk masa yang akan datang dengan puncak banjir kondisi eksisting. Hasilnya, sebagaimana ditampilkan dalam Tabel 2, menunjukkan bahwa debit banjir mengalami kenaikan berkisar antara $25,5 \%$ sampai dengan $31,5 \%$ tergantung dari kala ulangnya. Debit dengan kala ulang tinggi, secara kuantitaif mengalami kenaikan yang lebih tinggi, dibandingkan dengan debit dengan kala ulang yang lebih rendah. Sebaliknya, secara prosentase, debit dengan kala ulang rendah mengalami kenaikan yang lebih tinggi dibandingkan dengan debit dengan kala ulang tinggi.
Tabel 2. Perubahan debit puncak Banjir Kanal Banjir Timur saat ini dan masa yang akan datang

\begin{tabular}{|c|c|c|c|c|}
\hline \multirow{3}{*}{$\begin{array}{c}\text { Kala } \\
\text { ulang } \\
\text { (th) }\end{array}$} & \multicolumn{2}{|c|}{$\begin{array}{c}\text { Debit banjir } \\
\text { puncak rencana } \\
\left(\mathrm{m}^{3} / \mathrm{s}\right)\end{array}$} & \multicolumn{2}{|c|}{$\begin{array}{c}\text { Perubahan } \\
\text { debit puncak }\end{array}$} \\
\hline & & Prediksi & & \\
\hline & Saat ini & $\begin{array}{c}\text { yang } \\
\text { akan } \\
\text { datang }\end{array}$ & $\mathrm{m}^{3} / \mathrm{s}$ & $\%$ \\
\hline 2 & 47,93 & 63,04 & 15,10 & 31,5 \\
\hline 5 & 65,11 & 84,78 & 19,67 & 30,2 \\
\hline 10 & 78,14 & 100,58 & 22,44 & 28,7 \\
\hline 25 & 93,92 & 119,67 & 25,75 & 27,4 \\
\hline 50 & 105,07 & 133,09 & 28,02 & 26,7 \\
\hline 100 & 115,89 & 146,10 & 30,21 & 26,1 \\
\hline 200 & 126,48 & 158,76 & 32,28 & 25,5 \\
\hline
\end{tabular}

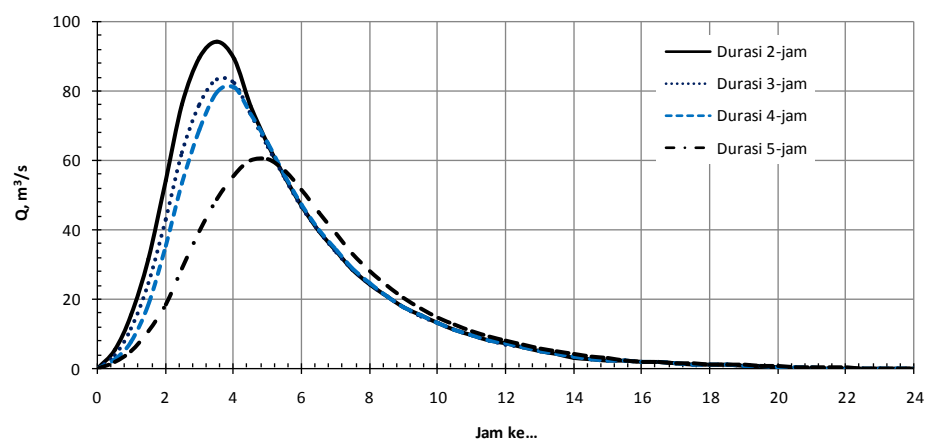

Gambar 6. Hidrograf banjir rencana DAS Kanal Banjir Timur untuk berbagai durasi hujan (hidrograf banjir kala ulang 25-tahunan untuk berbagai durasi hujan)

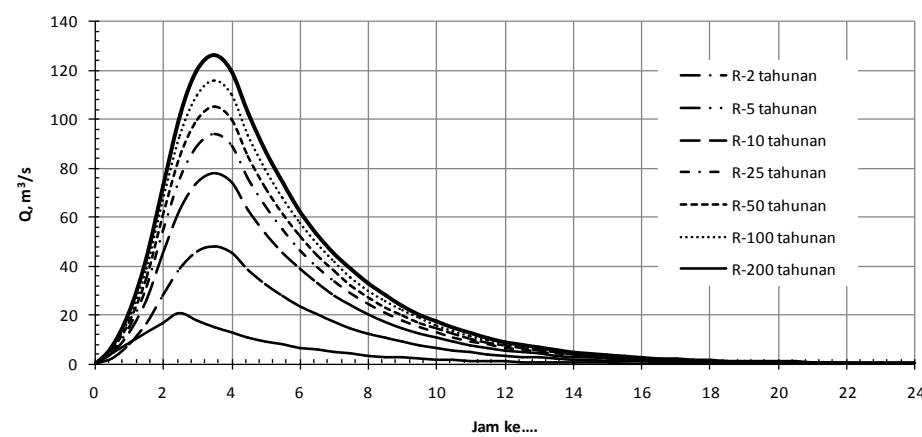

Gambar 7. Hidrograf Banjir Rencana DAS Kanal Banjir Timur untuk berbagai kala ulang berdasar hujan rencana saat ini (hidrograf banjir kala ulang untuk durasi hujan 2 jam)

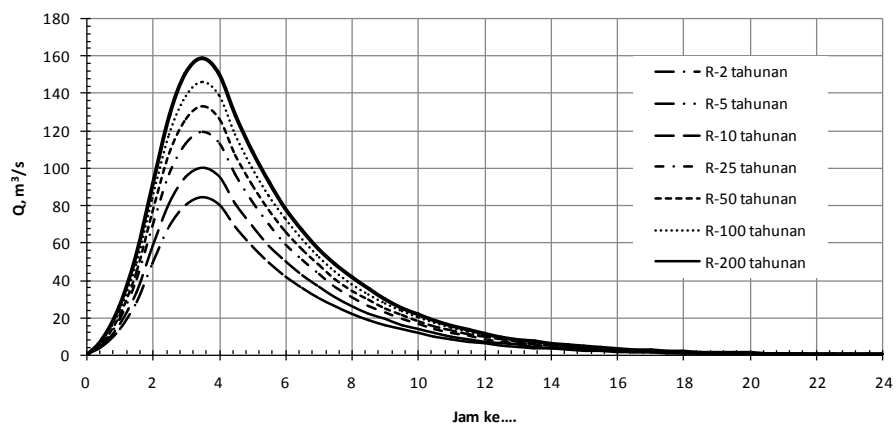

Gambar 8. Prediksi Hidrograf Banjir Rencana DAS Kanal Banjir Timur untuk berbagai kala ulang berdasar hujan rencana masa yang akan datang (hidrograf banjir kala ulang untuk durasi hujan 2 jam) 


\section{Kesimpulan}

Berdasarkan hasil analisis dan pembahasan sebagaimana diuraikan pada ba-bab sebelumnya dapat disimpulkan hal-hal sebagai berikut:

1. Perubahan iklim mengakibatkan perubahan karakteristik hujan di DAS Kanal Banjir Timur, yaitu tinggi hujan tahunan dan hujan harian maksimum cenderung mengalami peningkatan, sedangka jumlah hari hujan cenderung menurun. Tinggi hujan tahunan meningkat ratarata $22,64 \mathrm{~mm} /$ tahun, sedangkan hujan harian maksimum meningkat rata-rata $2,56 \mathrm{~mm} / \mathrm{tahun}$, dan jumlah hari hujan berkurang rata-rata 4 hari/tahun.

2. Debit banjir rencana DAS Kanal Banjir Timur diprediksi akan mengalami kenaikan berkisar antara 32,28 m3/s (25,5\%) untuk kala ulang 200-tahunan sampai dengan 15,10 m3/s $(31,5 \%)$ untuk kala ulang 2-tahunan. Debit dengan kala ulang tinggi, secara kuantitaif mengalami kenaikan yang lebih tinggi, dibandingkan dengan debit dengan kala ulang yang lebih rendah. Sebaliknya, secara prosentase, debit dengan kala ulang rendah mengalami kenaikan yang lebih tinggi dibandingkan dengan debit dengan kala ulang tinggi.

\section{Saran}

Memperhatikan berbagai keterbatasan dan kekurang dalam penelitian ini, maka beberapa saran untuk tindak lanjut penelitian adalah sebagai berikut:

1. Analisa pengaruh perubahan iklim terhadap karakteristik hujan memerlukan data historis yang sangat panjang. Dalam penelitian ini panajang data yang digunakan sangat terbatas, kurang lebih hanya 30 tahun, sehingga untuk hasil yang lebih akurat diperlukan penambahan panjang data.

2. Jumlah stasiun hujan di Indonesia, khususnya di DAS Kanal Banjir Timur, sebenarnya cukup banyak, namun ketersediaan data (kontinuitas, kualitas, dan kelengkapan) data sangat tidak memadahi. Perlu dilakukan rasionalisasi stasiun klimatologi.

3. Ketidak tersediaan data debit banjir dan /atau hidrograf banjir mengakibatkan kesulitas untuk melakukan validasi hasil penelitian. Oleh karena itu disarankan untuk memasang dan/atau mengoperasikan stasiun Automatic Water Level Recorder (AWLR) di setiap sungai dan anak sungai.

\section{Ucapan Terimakasih}

Ucapan Terima Kasih disampaikan kepada Departemen Teknik Sipil Fakultas Teknik Universitas Diponegoro atas dukungan dana untuk penelitian ini.

\section{Daftar Pustaka}

Emanuel, K., 2005. Increasing Destructiveness of Tropical Cyclones Over the Past 30 Years, Nature 436: 686-688.

Intergovernmental Panel on Climate Change (IPCC), 2008. Climate Change and Water, IPCCXXVIII/Doc.13, 111.

Intergovernmental Panel on Climate Change (IPCC), 2007. Climate Change 2007: Synthesis Report. Geneva, Switzerland: IPCC.

LAPAN, 2002. Laporan Perubahan Iklim, LAPAN, Bandung.

Murdiyarso D., 2003. Protokol Kyoto: Implikasinya bagi Negara Berkembang, Penerbit Buku Kompas, Jakarta.

O’Gorman, P.A., 2015. Precipitation Extremes Under Climate Change, Current Climate Change Reports 1, 49-59.

PEACE., 2007. Indonesia and Climate Charge: Current Status and Policies, World Bank, DFID, PEACE, Jakarta.

Suripin, dan Hilmi, M., 2015. The Lost of Semarang Coastal Area due to Climate Change and Land Subsidence, International Conference on Tehnique, Development and Management of Delta Area, February 20, 2015, Semarang.

Turyanti, A., 2006. Dampak Pemanasan Global, BMG, Bandung.

USACE., 2010. Hydrologic Engineering Center's River Analys System User's Manual, U.S. Army, Washington, DC.

WWF, 2012. Climate Change in Indonesia: Implications for Humans and Nature, http://wwf.panda.org/about_our_earth/aboutcc/pro blems/rising_temperatures/hotspot_map/indonesia. cfmBrown, L.C. dan Barnwell, T.O., 1987. The Enhanced Stream Water Quality Models QUAL2E and QUAL2EUNCAS: Documentation and User manual, US EPA, Georgia. 